\title{
Preliminary Results of the South Vanuatu Archaeological Survey: Cultural Landscapes, Excavation, and Radiocarbon Dating
}

\author{
$\mathbf{\Delta} \cdot \mathbf{\Delta} \cdot \mathbf{\Delta}$ \\ James L. Flexner, Stuart Bedford, Frédérique Valentin, Richard Shing, \\ Takaronga KuAutongA, and Wanda Zinger
}

\begin{abstract}
South Vanuatu was an important hub of settlement and interaction in the tropical southwestern Pacific. A recent field project, the South Vanuatu Archaeological Survey, has begun carrying out field research, focusing initially on the islands of Futuna, Aniwa, and Tanna. This work builds upon pioneering research carried out in the 1960s, which in these islands has not been followed up until the last five years or so. We present initial findings from survey and test excavations carried out in 2016, including new radiocarbon dates for the region and the discovery of pottery on Tanna. Keywords: Melanesia, Vanuatu, cultural landscapes, archaeological survey, radiocarbon dating.
\end{abstract}

\section{INTRODUCTION}

At the 1961 meeting of the Pacific Science Congress, fieldwork in New Hebrides (now Vanuatu) was identified as a key area for an initiative with an eye toward expanding archaeological knowledge about Oceania. Archaeologist José Garanger was sent to explore the central islands, while Richard Shutler and Mary Shutler carried out fieldwork in the south of the archipelago (Bedford 2006:14-17; Shutler and Shutler 1966:157).

Shutler and Shutler focused on excavating cave and rockshelter sites, particularly on the islands of Futuna, Aneityum, and Tanna. Of the other southern islands, they also did a limited survey on Erromango, but no work was carried out on Aniwa. At the end of their southern island fieldwork, they carried out a series of excavations on Efate. One of the objectives of their work was to find datable deposits relating to the initial occupation of the region. However, their research on the southern islands tended to be

James L. Flexner is a Lecturer in Historical Archaeology and Heritage in the Department of Archaeology at the University of Sydney. Stuart Bedford is Senior Lecturer in the Department of Archaeology and Natural History, The Australian National University and Associate of the Max Planck Institute for the Science of Human History. Frédérique Valentin is a Researcher in the Centre National de la Recherche Scientifique in France and Maison de l'Archéologie et de l'Ethnologie à Nanterre UMR 7041. Richard Shing is Director of the Vanuatu Cultural Centre. Takaronga Kuautonga is the Vanuatu Cultural Centre Fieldworker for Futuna Island. Wanda Zinger is a doctoral student at the Muséum National d'Histoire Naturelle in France. 
associated with sites that primarily dated from the past 1000 years or less, including the human burials in caves on Futuna and Tanna and the cave and open sites on Aneityum (Shutler and Shutler 1966; Shutler et al. 2002; Valentin et al. 2011). One of the contentious issues with their early research is that many of the radiocarbon dates they published (Shutler 1973) would now be considered unreliable by current standards of chronometric hygiene (Petchey et al. 2011).

After the Shutler and Shutler campaign, other archaeological research did occur on a restricted number of islands in southern Vanuatu. Les Groube returned in 1972 to both Aneityum and Erromango, and it was his research on the former that inspired Matthew Spriggs to complete a $\mathrm{PhD}$ focusing on the extensively irrigated agricultural systems of that island (Groube 1975; Spriggs 1981). After receiving his doctorate, Spriggs returned in 1983 to Aneityum and Erromango. He was the first archaeologist to identify a colonizing Lapita site in Vanuatu (Spriggs 1984). Research continued on Erromango in the 1990s as Bedford focused on initial colonizing sites, including Lapita at Ponamla and Ifo (Bedford 2006:32-39), and Meredith Wilson recorded rock art (Wilson 1999, 2002). Further excavations on Aneityum from 2012 to 2015 focused on initial colonization and missionization, with the first Lapita site being found at Anelcauhat in 2013 (Bedford et al. 2016). On Tanna, the only excavations pertaining to the pre-contact era are related to deposits underlying nineteenth-century mission sites (Flexner 2016), including an 800-year-old burial on a raised dune site at Kwamera (Flexner and Willie 2015). In short, although an increasing amount of data has been generated over the past five decades or so, there has been no comprehensive regional survey that could tie together these data points at a higher level.

More than fifty years after Shutler and Shutler's pioneering work in the region, a new South Vanuatu Archaeological Survey (SVAS) has been initiated to explore the long-term histories, settlement patterns, and interisland networks of Oceanic people living in these islands over the last 3000 years. South Vanuatu was an important hub for human settlement in the western Pacific, with connections reaching west to the Loyalty Islands and New Caledonia and east into Polynesia (Capell 1958; Dubois 1996). The biogeographic variability of the islands within such a small area also provides an opportunity to assess models of agricultural adaptation and intensification and sociopolitical complexity in Oceanic societies.

Vanuatu is one of the most linguistically dense regions of the world. Recent estimates figure that somewhere between 80 to over 100 languages are spoken among a population that has grown in the past decade from roughly 200,000 to 270,000 people (Crowley 2000; François 2012). This diversity is amply apparent in southern Vanuatu (Lynch 2001). In a population of only 25,000-27,000 people, Tanna island (one of the islands being surveyed for this project) currently has five languages and as many as 25 dialects; historically, there were likely many more (Nehrbass 2012:1). (Population estimates are notoriously sketchy in rural Vanuatu, where people often live in remote and difficult to access hamlets because of the rugged terrain of many of the islands.) Futuna and Aniwa each have one main language, but these two Polynesian languages are unrelated to the languages of neighboring islands. Extinct languages are remembered by local elders on Futuna and Tanna.

How can we account for the emergence (and subsequent loss) of this kind of cultural diversity using archaeological data in conversation with other lines of evidence, such as demographic, linguistic, or ethnohistoric data (Kirch and Green 1987, 2001; Kirch and Rallu 2007)? Related to this question are ongoing debates about how best to model the 
human settlement of island environments and how this history relates to cultural diversity within the Pacific region (Addison and Matisoo-Smith 2010; Burley 2013; Kirch 2010b; Specht et al. 2016; Terrell 2011) and elsewhere (Hofman et al., 2007).

As "Polynesian outliers," Futuna and Aniwa stand out in southern Vanuatu (see below). Major questions remain to be answered about the archaeology of such Polynesian outliers, that is, islands that lie geographically outside of the great Polynesian triangle, but have populations speaking Polynesian languages (Feinberg and Scaglion 2012; Kirch and Yen 1982; Leach and Davidson 2008). Polynesian outliers are often relatively small islands that are either geographically remote (e.g., Futuna) or situated very close to larger, more populous islands (e.g., Aniwa). From the perspective of such Polynesian outliers, how is their geographic location reflected in their longterm histories of human settlement and their interactions with neighboring islands? Recent research has pointed to the general importance of refining settlement chronology, expanding data on interactions between so-called "Polynesian" and "Melanesian" populations, and crafting better understanding of how these complex and probably intertwined cultural identities evolved in the past (Carson 2012; Kirch and Swift 2017). Research in southern Vanuatu has so far proven somewhat equivocal in relation to some of these discussions. As Shutler and Shutler (1967:98) pointed out following their fieldwork on Tanna and Futuna, "The artifacts which come from areas in which Melanesian languages are spoken today are indistinguishable from those found on Polynesian outliers."

Finally, there is the question of the centralization of power among leaders known throughout Oceania as "chiefs" (Earle and Spriggs 2015). The islands of Erromango and Aneityum had relatively centralized hierarchies with paramount chiefs, which can be compared with the much more heterarchical society of Tanna (Bonnemaison 1994; Brunton 1979; Flexner 2016:18-21, 61-66; Spriggs 1981, 1986). The social structures of Futuna and Aniwa are less well documented, though the ethnohistory of Futuna suggests an affinity with the Tannese tendency toward resisting the establishment of lasting, entrenched hierarchies (Keller and Kuautonga 2007). What can we say about the historical trajectories of chiefly society on these islands and how do they covary in relation to biogeographical, cosmological, ritual, or economic variables? What can archaeology tell us about the evolution of chiefly power on these islands? Does it correlate in some way with the evolution of Polynesian identities or are entanglements with the local Melanesian systems more significant?

To address these broader research questions, we must begin with some fundamental new data. One of our primary aims is to refine the chronologies for settlement in the islands of southern Vanuatu. When were the larger and smaller islands in southern Vanuatu originally settled? What is the evidence for population expansion and subsequent waves of migration in those islands? Particularly, when did Polynesian people arrive, what was the scope of their arrival, and what was the nature of their interactions with extant Melanesian populations? The other primary objectives of the project involve expanding our understanding of settlement patterns through time, particularly on the small islands of Futuna and Aniwa, and the history of interisland interactions across shorter as well as longer distances. This means tracing patterns of exchange within the region and to close neighboring groups such as the Loyalty Islands, while also looking further afield to interactions with Fiji and West Polynesia. The settlement pattern surveys will focus on long-term practices of both permanent and temporary domestic habitations, agricultural expansion and intensification, the 
emergence of chiefly heterarchies, and ritual landscapes. Another important outcome of the SVAS project will be the study and repatriation of the human remains recovered by Shutler and Shutler, though this is beyond the scope of this article.

Here, we report the preliminary results of research based on the initial field season carried out in 2016 and consider broad implications and future directions for research signaled by our results. There are limitations to the data acquired so far as the field season in 2016 was only three weeks long. It involved mostly surface survey and excavation of a small number of test pits on Tanna, Futuna, and Aniwa. Our initial excavations in 2016 targeted near-shore environments that elsewhere in Vanuatu often contained stratified archaeological deposits up to 3000 years old (Bedford 2006). As explained below, this turned out not to be the case in Futuna and Aniwa. Evidence from Futuna indicates rapid coastal subsidence, while Aniwa is subject to dramatic tectonic uplift. The surface survey provided information about cultural landscapes, however, and gave us a sense of the range of other potential excavation sites.

The fieldwork did return a range of new data relevant to understanding the history of southern Vanuatu over the last 1000 years or more and suggested directions for future research. Specifically, excavations seeking evidence for early Lapita settlement (ca. 3000 B.P.) will need to target different environments, including possible raised palaeoshores on Aniwa. In the following pages, we outline the geography, history, and cultural landscapes of Aniwa, Futuna, and Tanna, followed by a summary of the fieldwork data from 2016, including new radiocarbon dates and ceramic evidence, before closing with some initial conclusions and directions for future research.

\section{THE SETTING}

South Vanuatu's TAFEA Province is recognized as consisting of five islands from north to south: Erromango, Tanna, Aniwa, Futuna, and Aneityum (two small, uninhabited islands to the south called Matthew and Hunter are currently disputed between Vanuatu and France) (Fig. 1). Geographically, the islands vary from the older high volcanic islands of Erromango and Aneityum to the still-active volcanic island of Tanna. Aniwa is a small coral atoll very close to Tanna, while Futuna is a makatea (raised coral) island separated from the rest of the group by a deep-sea channel (Carney and MacFarlane 1971; Colley and Ash 1971; Neef and McCullough 2001). The islands in the province are intervisible and have similar endemic flora and fauna, though Futuna and Aniwa have slightly different soils and hydrology, which may have influenced the agricultural history of the islands.

Southern Vanuatu was initially settled around 3000 years ago by people from what is generally referred to as the Lapita Cultural Complex; these people would have come from islands to the north (Bedford 2006; Bedford and Spriggs 2014). Lapita people were long-distance Oceanic navigators who made a distinctive style of dentatestamped pottery found across the southwest Pacific from the Bismarcks and New Guinea to Tonga and Samoa (Sand and Bedford 2010; Sand et al. 2015). Lapita pottery has been found at two sites on Erromango (Bedford 2006) and one site on Aneityum (Bedford et al. 2016), but the early history of Tanna, Futuna, and Aniwa before about 1000 B.P. remains essentially unknown.

The next major wave of migration came some time within the past 1000 years, this time by groups of Polynesian-speaking people from the east, resulting in the formation of the Polynesian outliers. Futuna and Aniwa are two islands that fall within this group 


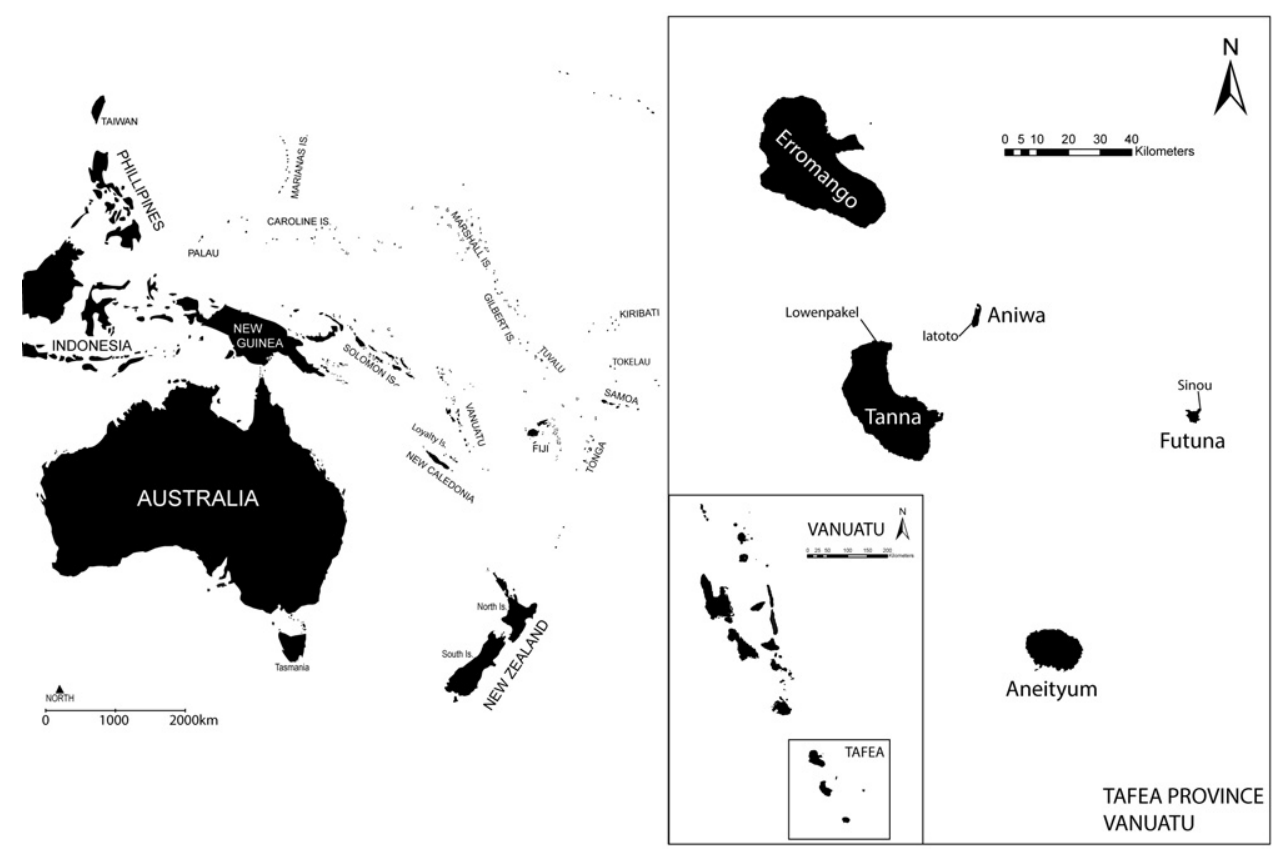

Fig. 1. Map of western Pacific and South Vanuatu, including the location of excavated sites discussed in text.

(Capell 1958), though there is further evidence for Polynesian influence in southern Vanuatu, for example with Tanna's kava rituals (Lynch 1996).

European contact in the region began with Cook in 1774; he stopped at Erromango briefly before spending several weeks on Tanna, where he learned the names of the neighboring islands (Beaglehole 1969:475-509). The major nineteenth century European colonizers in southern Vanuatu were Christian missionaries. Along with recently converted catechists from Polynesia, European evangelists came by the dozens beginning in 1839; major waves of missionaries arrived between the 1850s and 1880s (Adams 1984; Flexner 2016; Liua'ana 1996). Other nineteenth century contacts occurred with sandalwood traders, particularly on Erromango (Shineberg 1967), and through the labor trade, which took islanders, primarily young men, from the islands to work on plantations in Australia and elsewhere in Oceania (Scarr 1967). A host of diseases were introduced to the islands from the earliest periods of sustained contact with Europeans, resulting in drastic levels of depopulation (McArthur 1981). The most reliable data is available for Aneityum, where it has been calculated that some 90 percent of the population was lost by the late nineteenth century (Spriggs 2007). Even today, the populations on the islands remain far below pre-contact densities.

\section{CULTURAL LANDSCAPE SURVEY}

As elsewhere in Vanuatu, oral traditions are inscribed on the landscapes of Aniwa, Futuna, and Tanna, both of actual historical events and ancestors, and more mythical and spiritual histories (Flexner 2014; Garanger 1972). Entangled with these stories are the land divisions that structure the political economy of the islands (Bonnemaison 
1994; Lindstrom 1990; Van Trease 1987). Traditional cultural landscapes provide an ethnographic baseline for interpreting patterns of land tenure, ecology, and political economy in the deeper past, representing the endpoints of the historical trajectories of island societies.

\section{Aniwa}

Aniwa is a low coral spit with the long axis oriented roughly north-south, approximately $7 \mathrm{~km}$ long and $1.5 \mathrm{~km}$ wide. The highest point on the island is $42 \mathrm{~m}$ a.s.l., with most of the island not more than $20 \mathrm{~m}$ a.s.l. Villages traditionally clustered around the coast of the island until people were encouraged by early missionaries to move to higher parts of the center of the island, where they have remained ever since. A number of cave and rockshelter sites exist among the raised limestone reef terraces, offering currently untested potential for stratified archaeological deposits. One such cave is called Punanga Ruru (lit. "owl cave”). Surface scatter suggests the cave may contain deposits with concentrations of faunal remains. A number of other prospective caves and rockshelters are located around the large lagoon in the northern part of the island. While beaches are frequent along the sheltered western coast, passages through the fringing reef where we would expect to find sites of early settlement are few. One of the areas thought to have good potential for evidence of early settlement is at Iatoto, where back beaches front a reef passage (Fig. 2). Another is at Imarae, where another reef passage first attracted missionary interest and permanent settlement.

There are remarkably few ethnographic accounts of early Aniwan culture (Gray 1894; Humphreys 1926:120), which was transformed by nineteenth century missionary activity (Paton 1907) combined with drastic population decline (McArthur

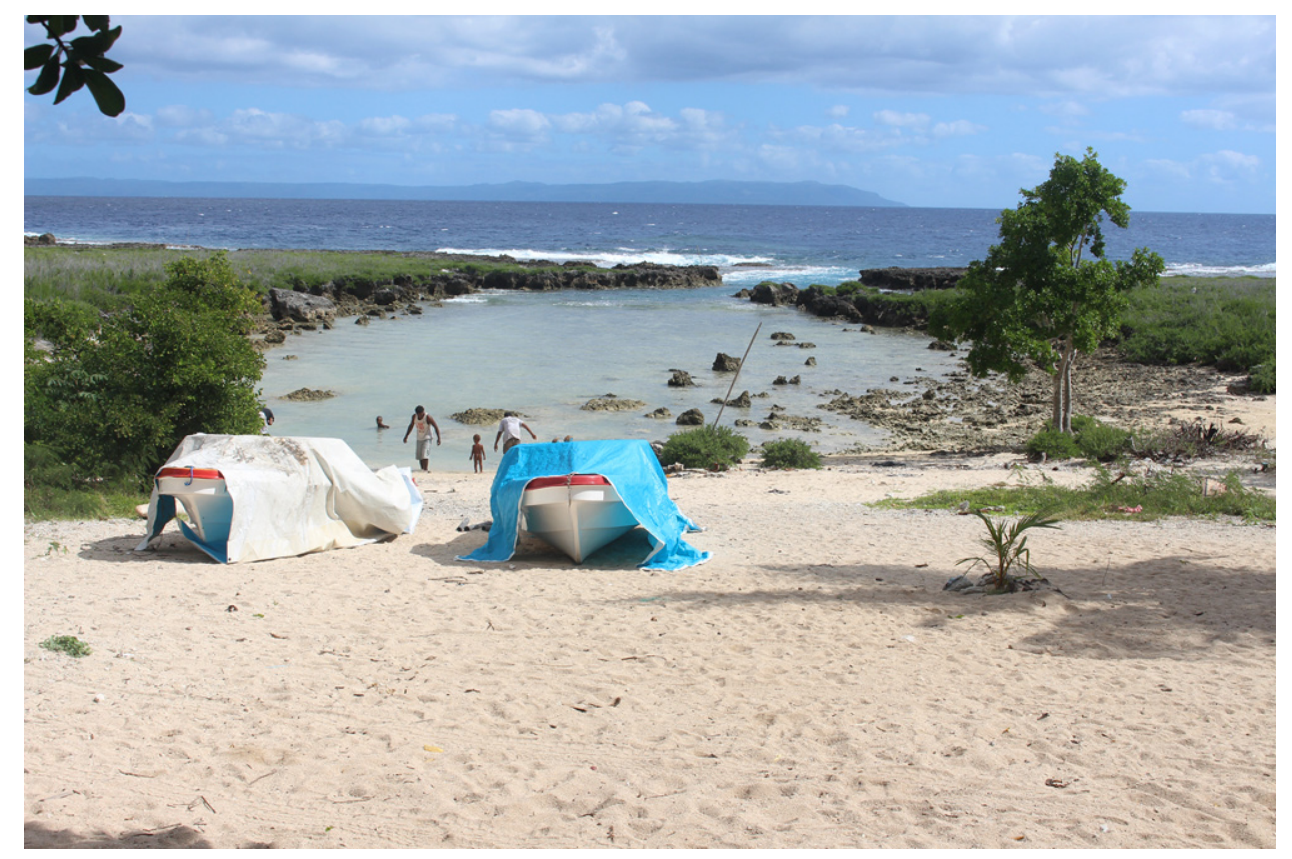

Fig. 2. Reef passage at Iatoto still in use (northern Tanna visible in the background). 
and Yaxley 1968:11). The mission station was established in 1866, and its remains constitute an important historical site for living Aniwans. Visible remains include the coral block and boulder lime-mortared foundations and cellar of the mission house, ruins of an orphanage, the footings of a late nineteenth-century church (the third on the site), and an extensive mission-period cemetery. A memorial marker on the mission well is culturally significant for the history of conversion on Aniwa. John G. Paton's mission was located at Imarae, which was the home of Tagaro, the sea snake god. According to local traditions and missionary accounts, Paton's ability to dig a freshwater well on this ground won him the respect of the chiefs, who convinced the people to convert to Christianity (Paton 1907:176-192).

Another tradition tells the story of Faturere (lit. "flying stone"), a massive coral boulder located on the southeast coast that is said to have been tricked into flying from the high plateau of Futuna by another magic stone. The land is richly divided in terms of place names, though associated stories may be difficult to identify. Traditionally, the island was divided into two major halves, Iafatu/Iefotuma to the south and Sura/ Surama to the north (see Capell 1958:1 for alternate names). There were also smaller land divisions around the island. However, it is unclear from ethnographic accounts whether the land divisions correlated one-to-one with kinship or clan membership; it is probable that as elsewhere in the region they did not. Rather, people often had plots of land on both sides of the division, reflecting a complex network of social-ecological relationships. Intriguingly, there are two stones outside of a Futuna village called Sura and Fatu that are said to represent the two moieties on that island (Keller and Kuautonga 2007:64); so it is possible that this pattern did exist at some point, but was simply abandoned in the recent past.

As on Futuna (see below), Aniwa had sacred spaces called marae; however, these are not the monumental stone constructions typically found in East Polynesia. Rather, they look more like the imwarim (kava-drinking grounds) of Tanna (Brunton 1989:130-138; Lindstrom 1996). We recognize that the term malae was often used to refer to open spaces for social and ritual gatherings in West Polynesia (e.g., in Samoa, Martinsson-Wallin 2014:258; and Tonga, Clark 2014:238). Thus, whether the form of the Aniwan and Futunese marae was introduced from Polynesia or the Polynesian term was applied to an existing ritual space is yet to be determined. Regardless, considering its close proximity to the much larger island, and its limitations in terms of agricultural productivity, we might hypothesize that Aniwa functioned in some way as a satellite of Tanna, albeit one with a distinctive language. Oral traditions on Aniwa recall shellfish gathering and other activities that took advantage of the island's rich reef, mangrove, and lagoon environments as being a key element of exchange with Tanna. In exchange for marine resources, Aniwans received from Tanna agricultural produce and other items such as basaltic oven stones that do not occur on Aniwa itself.

\section{Futuna}

Futunese joke that their island is "fatuana" or "just a rock" (Keller and Kuautonga 2007:41). The island is just over $5 \mathrm{~km}$ across at its widest, jutting out from the Pacific Ocean with a high point of $666 \mathrm{~m}$ a.s.l. The island has a small fringing coastal plain (called Romara), and then the ground rises steeply to a central plateau (called Tatapu or Tatafu) approximately $2 \mathrm{~km}$ in diameter. The island is divided into seven main wedgeshaped districts that run from the cliff tops to the fringing reef. From the northeast and 
proceeding clockwise, the districts are Pau, Iraro, Matagi, Iakana, Iasoa, Mouga (sometimes divided into "upper" and "lower" subdistricts), and Hsia (Keller and Kuautonga 2007:47). The plateau has a central depression that was treated as sacred (hence the "tapu [taboo]" in Tatapu). This was surrounded by garden plots on the flat land around the edge of the plateau.

The steep slopes are covered with stone terraces on the leeward (dry, north and west) side to retain soil for rainfed agriculture and on the windward (wet, south and east) side to permit pondfield irrigation. The terraces on both sides are called ropae (Fig. 3). Individuals can have patches within the ropae in different districts of the island. It is very much tapu (prohibited) to trespass on another's garden plot without an invitation, so the horizontally running stone walls that define plot edges connect to vertically running walls that serve as paths on which people travel to and from their patches in the ropae system. The primary staples (Dioscorea yams on the leeward side and Colocasia taro on the windward side) were grown in the central portion of the ropae. Along the fringes next to the vertical paths, people grew sugarcane, bananas, the intoxicating kava plant (Piper methysticum), and other vegetables. Most of the windward ropae were abandoned in recent memory, though some efforts are being undertaken to revitalize the irrigated terraces.

Greater investment in agricultural intensification on Futuna may reflect the geographic remoteness of the island. This is not to say Futuna was isolated, however. There is clear evidence of contact with Aneityum and Tanna, which are intervisible. The strong currents of the deep New Hebrides Trench may have made navigation

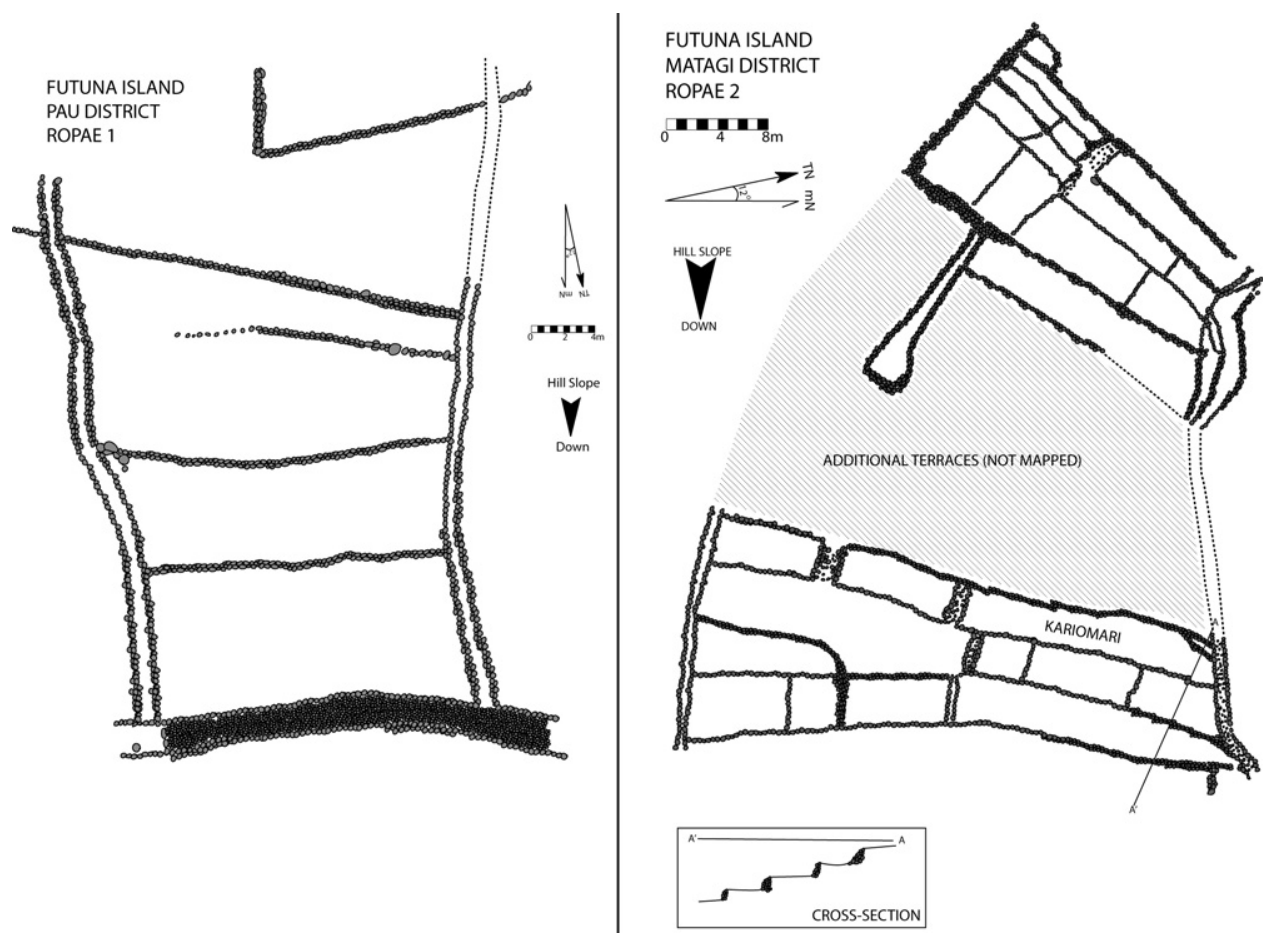

Fig. 3. Examples of areas of ropae on the dry (left) and wet (right) sides of Futuna. 
difficult at times (Neef and McCullough 2001), however, so Futuna needed to be more self-sufficient than Aniwa.

Close connections to Tanna are nonetheless apparent. Futunese society was divided into two moieties: Kaviameta and Namruke. Namruke is characterized by subtlety and wisdom, whereas Kaviameta is direct and often aggressive (Keller and Kuautonga 2007:61-64). This is basically identical to the moieties on Tanna, where the names are quite similar (Numrukuen and Koyometa). Numrukuen is considered the "elder brother," powerful in magic and strategy, while Koyometa is considered strong in battle (Bonnemaison 1994:152-153). On Futuna, the two moieties were arranged such that both sides contributed to controlling various phenomena having to do with weather, crop growth, animal husbandry, marine resource use, and illness. Each side had a high chief, with various experts responsible for affecting environmental or spiritual phenomena by magical or supernatural means (Keller and Kuautonga 2007:61). One of the ways that the dual structure of society was reflected in the landscape on Futuna is in the sacred spaces (marae). As on Aniwa, these sacred spaces were open grounds for dancing and drinking kava and are more like the imwarim of Tanna than the marae of East Polynesia. Each village on Futuna had two marae spaces, one for Kaviameta and one for Namruke.

\section{Tanna}

Tanna is a much larger island than Futuna and Aniwa, with a surface area of $550 \mathrm{~km}^{2}$. The island's most striking feature is its active volcano, Iasur, located in the south, which was an explicit reference point for Cook during his navigation of the area (Beaglehole 1969:481). The volcano may have also served as a beacon for earlier Oceanic navigators encountering the islands of what is now southern Vanuatu.

As a larger island with rich soils in the south, Tanna's agricultural potential and population has always been much greater than that of the nearby small islands of Futuna and Aniwa. Unlike Futuna and Aniwa, where Polynesian languages are spoken, five different Austronesian languages are spoken in Tanna. However, evidence for Polynesian influence in Tanna is found in the terms used to refer to kava and its preparation and ritualistic consumption (Lynch 1996).

The cultural landscape of Tanna is structured by networks of linked hamlets, garden plots, and kava drinking and dancing grounds called imwarim (in the Nafe language of southern Tanna) (Brunton 1989). Garden plots are rainfed and used for growing root crops such as taro and yams, vegetables, bananas, sugarcane, and kava. Yams are often planted in mounds (takwu), which can be over $20 \mathrm{~m}$ in diameter. The daily kava ritual is central to the lives of Tannese men, who gather at the imwarim each evening to listen to the spirit of the intoxicating drink. This ritual is said to reflect the "atomistic" nature of Tannese society because after drinking each man retreats to his own corner of the imwarim to listen undisturbed to the "voice" of the kava (Brunton 1979:102).

The land divisions on Tanna (neteta in Nafe, lit. "canoe") also likely reflect this pattern toward fragmentation and decentralization on Tanna. Where the neighboring large islands of Aneityum and Erromango have a small number of land divisions (seven and six, respectively), each led by a paramount chief, Tanna has over 115 neteta (the number fluctuates because of disputed territories). Although there is a chiefly title, iani netata, which refers to the "speaker of the canoe," this title does not necessarily offer the kinds of authority given to paramount chiefs in many Oceanic societies. Rather, this 
and other titles such as iarumanu ("leader") are contested and flexible, giving different chiefs varying roles and levels of authority (Bonnemaison 1994; Guiart 1956; Lindstrom 1990).

While the Tannese are not generally known for massive stone constructions, there is an extensive landscape of stone walls and mounds in the far south of the island near Kwamera at a place called Kwaraka. Notably, Aneityum, which is an island covered in stone walls and terraces used to grow irrigated taro (Spriggs 1981), is visible from Kwamera, and there is other evidence for extensive contact between the two islands (Spriggs 1986).

At Kwaraka, there are two types of mounds; one is a conical form and the other is a flat-topped mound circumscribed by stacked stone walls on the outside with earth in the middle. Excavation of one of the conical mounds revealed that it had been constructed by heaping stones and earth along with pig bones, large shells, and red ochre cobbles, possibly as a single event. These kinds of mounds may have been created as part of some kind of feasting ritual (Flexner et al. 2016:42-43). The flat-topped mounds appear to be post-European contact in date, though further excavation is needed to understand their construction, use, and structure. At least one of these was used as a canoe mound in the 1800s, as recounted in local oral histories (Flexner et al. 2016:35-37).

\section{EXCAVATIONS AND PRELIMINARY DATING RESULTS}

Test pits were excavated at sites on the three islands in areas thought to hold potential for stratified archaeological deposits. The excavated areas included a back beach open site on Aniwa, a back beach behind a sandy promontory on Futuna, and rockshelter sites on the north of Tanna. These excavations primarily uncovered evidence for the use of coastal areas over the last 1000 years, which we interpret as temporary camping and picnicking taking place while people gathered marine resources. With a large amount of research covering Lapita and subsequent early settlement in Vanuatu, we see these findings as significant for beginning to understand patterns of everyday life from about 2000 B.P. through to the emergence of the "ethnographic present" in southern Vanuatu (Bedford and Spriggs 2008:97).

\section{Iatoto and Turinga, Aniwa}

Iatoto is one of the sheltered beaches on Aniwa with direct access to the open sea through a reef passage. Because of this feature, Iatoto was deemed as having high archaeological potential for locating early evidence of human activity. It is located at the southwest of the island with views of Tanna opposite. Limited uplift has created a wide exposed dead reef above the current reef and behind this is an extensive beach terrace running for several hundred meters along the coast. This is set against steep cliffs up to $10-15 \mathrm{~m}$ in elevation, behind which extensive flat terraces are located. The area directly inland from Iatoto is called Turinga, which was said to be an area of historic villages and is currently used for garden plots.

We excavated two $1 \times 1 \mathrm{~m}$ test pits in the old beach terrace at Iatoto and two additional $1 \times 1 \mathrm{~m}$ pits in Turinga. The two test pits on the beach terrace at Iatoto produced deeply stratified deposits that were excavated in spits and layers (Fig. 4). Neither test pit was completed to sterile, with TP1 reaching a depth of $1.0 \mathrm{mbd}$ (meters below datum, $0.1 \mathrm{~m}$ above the ground surface) and TP2 reaching $1.65 \mathrm{mbd}$. 

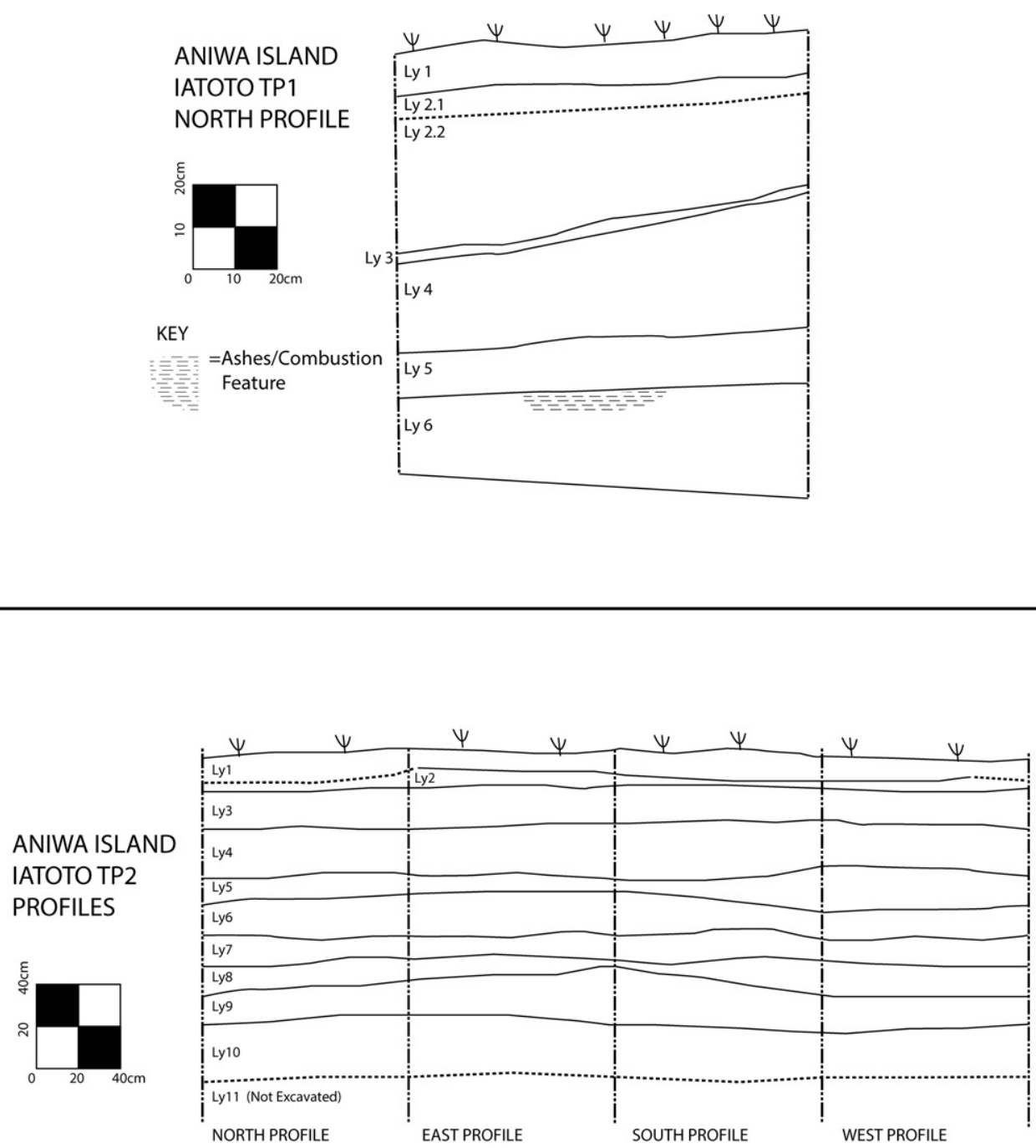

Fig. 4. Stratigraphic profiles of Iatoto TP1 (top) and TP2 (bottom).

Both test pits contained a series of firescoop deposits and hearth features at various depths. TP1 featured a particularly well-preserved small hearth feature containing charcoal and stones at the interface between Layer 5 and Layer 6. At a depth of 1-1.2 mbd in TP2, cultural deposits alternated with storm-washed sand deposits, indicating that this whole area would have been abandoned during severe weather events such as cyclones. Shell midden deposits were recovered and are being analyzed.

A single radiocarbon date from marine shell samples was recovered from each test pit (Table 1). The sample from TP1 came from a hearth feature at a depth of $1 \mathrm{mbd}$ and returned a date of 470-290 cal B.P. The sample from TP2 recovered from Layer 10 at a depth of $1.5 \mathrm{mbd}$ returned a date of $630-490 \mathrm{cal}$ B.P. These dates indicate that the beach terrace at Iatoto is relatively recent, probably dating to the last 1000 years. There has been rapid build-up, comprising both natural and cultural deposits, over that period. 
Table i. Radiocarbon Dates from Excavated Materials

\begin{tabular}{|c|c|c|c|c|c|c|c|c|}
\hline SAMPLE NUMBER & ISLAND & SITE & UNIT & LAYER/DEPTH & MATERIAL & $\delta^{13} \mathrm{C}$ & UNCALIBRATED DATE & $\begin{array}{c}\text { CALIBRATED DATE } \\
(95.4 \% \text { PROBABILITY })\end{array}$ \\
\hline WK 44330 & Aniwa & Iatoto & TP1 & Hearth feature $/ 100 \mathrm{cmbs}$ & Marine shell (Tectus pyramis) & $2.1 \pm 0.2 \%$ & $771 \pm 29$ в.P. & 470-290 cal B.P. \\
\hline WK 44329 & Aniwa & Iatoto & TP2 & Layer $10 / 150 \mathrm{cmbs}$ & Marine shell (Tectus pyramis) & $1.9 \pm 0.2 \%$ & $974 \pm 24$ в.P. & 630-490 cal B.P. \\
\hline WK 44334^ & Futuna & Sinou & TP1 & Layer $4 / 120 \mathrm{cmbd}$ & Nut charcoal & - & $413 \pm 20$ B.P. & $520-340 \mathrm{cal}$ в.P. \\
\hline WK 44335 & Futuna & Sinou & TP1 & Layer $7 / 260-280 \mathrm{cmbd}$ & Marine shell (Vasum turbinellus) & $3.3 \pm 0.3 \%$ & $1352 \pm 30$ в.Р. & 960-760 cal в.P. \\
\hline WK 44336^ & Futuna & Sinou & TP1 & Layer 7/260-280 cmbd & Wood charcoal (unidentified) & - & $1193 \pm 20$ в.P. & 1180-1060 cal в.P. \\
\hline WK 44337^ & Futuna & Sinou & TP2 & Layer $8 / 190 \mathrm{cmbs}$ & Marine shell (Turbo argyrostomus) & - & $1466 \pm 20$ B.P. & 1070-900 cal B.P. \\
\hline WK 44333^ & Tanna & Lowenpakel & TP5 & Hearth feature $3 / 113 \mathrm{cmbd}$ & Wood charcoal (unidentified) & - & $868 \pm 20$ B.P. & 900-720 cal в.P. \\
\hline WK 44332^ & Tanna & Lowenpakel & TP5 & Layer 4/127-150 cmbd & Wood charcoal (unidentified) & - & $1001 \pm 20$ в.P. & 970-830 cal в.P. \\
\hline WK 44331* & Tanna & Lowenpakel & TP5 & Layer 4/127-150 cmbd & Marine shell (Turbo argyrostomus) & $3.9 \pm 0.3 \%$ & $1587 \pm 20$ в.Р. & $1230-1010 \mathrm{cal}$ B.P. \\
\hline
\end{tabular}

Nine radiocarbon samples were dated using AMS $\star$ and standard radiometric methods. The radiocarbon determinations were calibrated by Fiona Petchey, University of Waikato, Radiocarbon Dating Laboratory using OxCal v. 4.2.4 (Bronk Ramsey 2013) and the IntCal13 atmospheric curve or the Marine 13 calibration curve (Reimer et al. 2013). Marine samples were calibrated with a Delta $R$ value of $29 \pm 28{ }^{14} \mathrm{C}$ yrs (Petchey et al. 2008). 
The two test pits on the upper terraces at Turinga revealed very hard-packed clayey soils almost devoid of archaeological materials down to the ancient uplifted reef at $0.40 \mathrm{mbd}$. A few European artifacts were found within the top $0.20 \mathrm{~m}$ only.

Geomorphologically, it is clear that the island of Aniwa is uplifting, with terraces such as the one at Iatoto only emerging within the more recent history of the island. Ample evidence is available for periodic habitation of the area during the last 1000 years, presumably for marine resource harvesting, which was a significant component of the local subsistence economy and important for exchanges with neighboring Tanna. This would have been particularly the case in east Tanna, where the erupting volcano can have negative effects on the local reefs; exchange with Aniwa would have been a valuable way to increase the availability of protein sources.

\section{Sinou, Futuna}

Sinou is at the northern point of Futuna. It is the only area of the island where a large open beach is backed by a slowly elevating beach terrace. This geological setting would have facilitated both easy canoe access and access into the interior, a typical setting for initial settlement. Everywhere else on the island, any beach landing is backed by steep cliffs, sometimes up to $80 \mathrm{~m}$ high. Sinou seemed to be the only locale where deposits earlier than 2000 B.P. might be located. However, we were told that some $50 \mathrm{~m}$ of the point had been removed by tropical cyclone Pam in 2015, and a preliminary survey near the active beach revealed a $20-30 \mathrm{~cm}$ thick clayey layer buried beneath stormwashed deposits. The geological information indicates that, unlike most other islands in Vanuatu, Futuna is subsiding and tilting rather than uplifting, although at what rate is not known (Neef and McCullough 2001).

Our initial observations appear to confirm this scenario. We excavated two test pits on the beach terrace behind the active beach (Fig. 5). TP1 was located nearer the sea, and all deposits were comprised primarily of beach sand of varying shades. Some were sterile beach storm deposits, while others indicated periods of humic accumulation. Fine lenses or patches of charcoal and ash and broken shell at different levels provided evidence for temporary activities on the beach such as camping or picnicking (activities still carried out in the area in the present).

Excavations in TP1 reached a maximum depth of $2.8 \mathrm{~m}$ where the clayey layer, seen in the beach section nearer the sea, was identified. It lay on top of sterile beach deposits. Dates were retrieved from a number of samples at different depths, including Layer 4 (520-340 cal B.P.) and Layer 7 (960-760 cal B.P. and 1180-1060 cal B.P.). TP2 was located some $15 \mathrm{~m}$ further inland. It displayed more concentrated cultural deposits and did not have the same depth of storm-washed sand. A combustion feature was situated within Layer 4 of TP2; it was interpreted as a small earth oven bordered by volcanic stones and contained a worked Tridacna shell. Excavation was completed when the clayey layer, which has been identified across the promontory, was found $1.9 \mathrm{~m}$ below the surface. A date of 1070-900 cal B.P. was recovered from a marine shell found in a midden deposit sitting on top of the clay layer. The dates confirm that this area of Futuna is submerging; dates of around 1000 B.P. are likely to be the earliest dates retrieved from this area of the island. As on Aniwa, the evidence is primarily for periodic and temporary use of coastal areas. However, unlike Aniwa, this area of the island appears to be subsiding, meaning the potential for finding earlier coastal deposits in this area may be limited. 

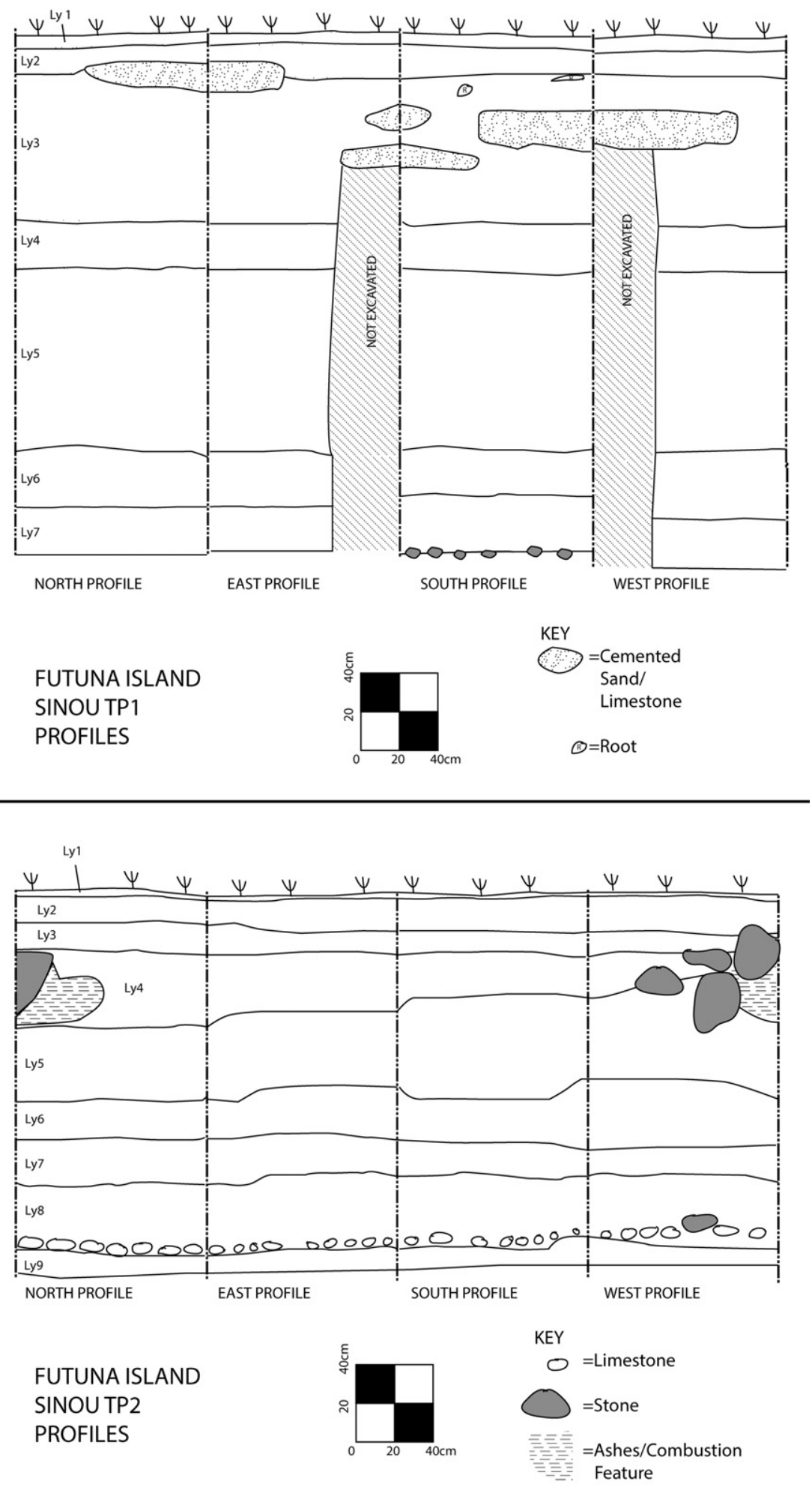

Fig. 5. Stratigraphic profiles of Sinou TP1 (top) and TP2 (bottom). 


\section{Lowenpakel, Tanna}

Lowenpakel is located right at the northern tip of Tanna in a sheltered bay and beach with a large perennial river. Bedford, Kuautonga, and Spriggs visited the area in 2012 as part of an earlier Australian Research Council-funded project focusing on colonizing sites. Potential colonizing sites are remarkably rare on western and northern Tanna. Most of the west coast consists of shallow fringing reefs backed by steep cliffs that are up to $80 \mathrm{~m}$ high. There are very few beaches along the entire coast and even fewer where sheltered passages are located. Lowenpakel faces the southeast coast of Erromango where the Lapita site of Ifo is located, so would have acted as an ideal location for settlement and as a link to the north and south (Bedford 2006:35-39).

In 2016, we only had time to target one side of the river, and so focused on the side with uplifted terraces and rockshelters to the rear. Four test pits were excavated across

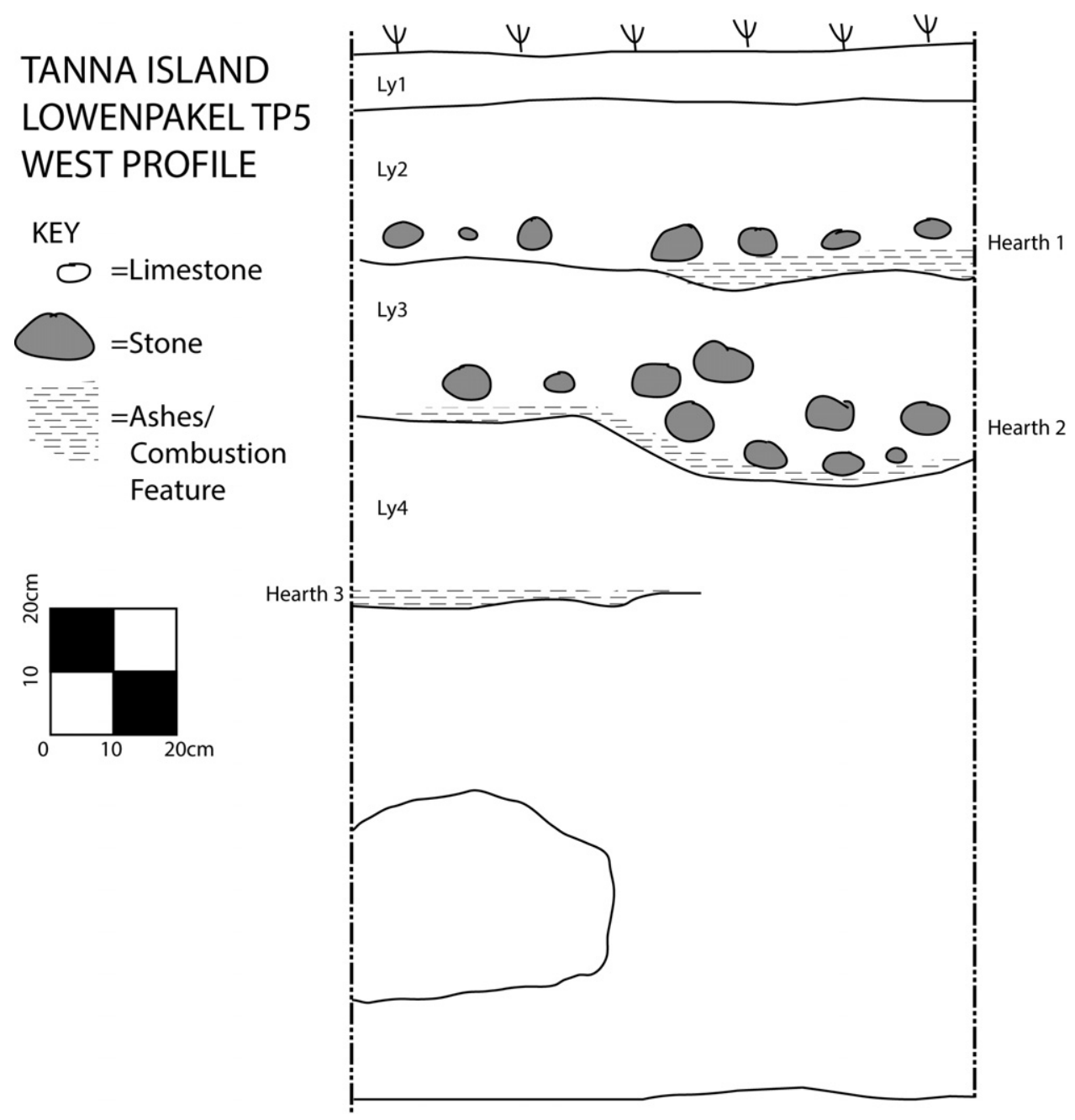

Fig. 6. Stratigraphic profile of Lowenpakel TP5, where pottery was recovered from below $120 \mathrm{cmbs}$. 


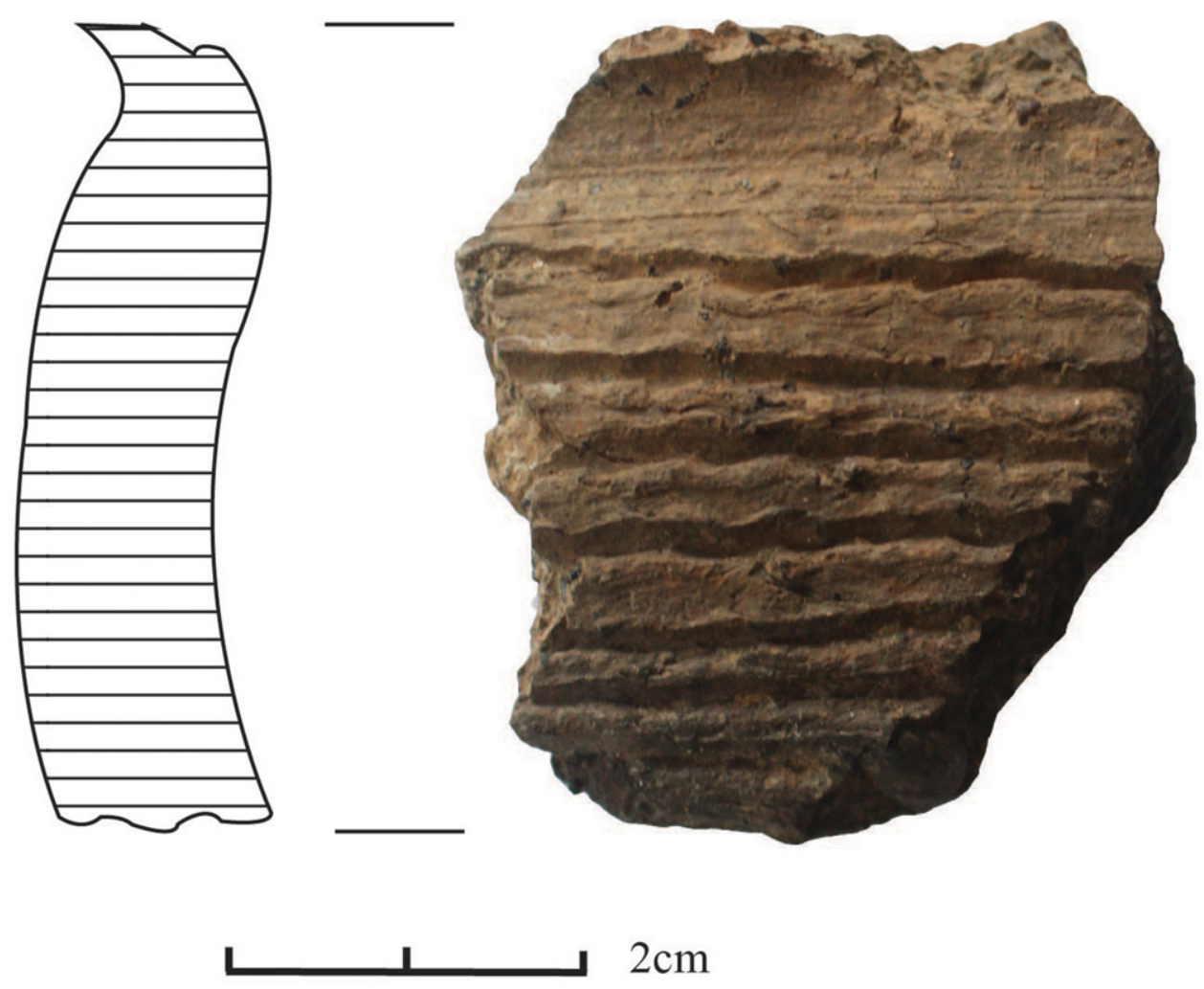

Fig. 7 Decorated ceramic sherd from Lowenpakel TP5.

the open terraces. All were striking for their sterility with limited stratigraphy and depth. All comprised hard clayey soils with few cultural deposits.

Subsequent investigations focused on two nearby cave sites. In only one of the caves, a single $1 \times 1 \mathrm{~m}$ test pit revealed deeply stratified deposits (Fig. 6). Charcoal from a hearth feature at $1.13 \mathrm{mbd}$ returned a date of 900-720 cal B.P.; two more dates (970-830 cal B.P. and 1230-1010 cal B.P.) were returned from a lower layer $(1.27-1.50 \mathrm{mbd})$. The most important find at this site was pottery sherds appearing from $1.2 \mathrm{mbd}$, a first for Tanna. There were a total of 8 sherds recovered from between 1.2 and $1.5 \mathrm{mbd}$. All were plain, except one sherd that was decorated with crudely applied horizontal parallel incisions (Fig. 7). This same sherd was the only one that gave an indication of vessel form. The shape of this neck and body sherd suggests that at least one of the pot forms at the site was a globular vessel with outcurving rim.

While further investigation of this cave site and the terraces on the other side of the river will be undertaken as part of the SVAS project, these first sherds provide a tantalizing suggestion that people may have continued to use pottery on Tanna for a significant span of time after it had been abandoned on neighboring islands. On nearby Erromango, ceramic evidence disappears from the archaeological record ca. 2000 B.P. (Bedford 2006:158), and on Aneityum, ceramic use appears to have dropped out even earlier (Bedford et al. 2016). Considering the lack of evidence for pottery on 
neighboring islands during this period, we would suggest that the sherds excavated in 2016 were most likely produced locally on Tanna. However, ongoing fabric analysis will help us determine whether the pottery came from a more exotic source.

\section{INITIAL CONCLUSIONS AND FUTURE DIRECTIONS}

As this is a preliminary report and most of the research has yet to be done, it would be premature to offer any conclusions. However, further research directions do emerge from the results of our initial field season. We have described the contemporary cultural landscapes of Aniwa, Futuna, and Tanna in detail. These landscapes, the linguistic variability, and the ethnohistoric records of chiefly systems, land divisions, and ritual life show great diversity within a relatively small area of the Pacific Ocean containing islands linked through maritime networks. The geographic sizes, locations, and varied soils of the islands influenced (though did not completely determine) these interisland relationships. To some extent, this may be reflected in the greater investment in agricultural intensification on Futuna compared to Aniwa, though in the latter case it is possible that there was also a greater focus on marine resource intensification. Aniwa may have had more of a satellite relationship with Tanna, while Futuna may have been more independent and self-reliant.

We recognize that the ethnographic baseline should not be projected uncritically into the past (Bedford and Spriggs 2008; Spriggs 1999), but in order to construct a model of historical trajectories, it is useful to start with the present and work backward (Steward 1942). Our excavations allow us to begin to trace further back historical patterns that may be continuous with the present, such as intermittent temporary occupation of coastal areas for marine resource gathering over the past 1000 years or more. We acknowledge the importance of working from the other direction as well by seeking evidence from early sites to understand the full spectrum of human behaviors and types of habitation in these islands. Excavations on Tanna also provided preliminary evidence of a discontinuity with the present, as the discovery of pottery, whether produced on Tanna or not, represents a material practice not known ethnohistorically. Future field seasons should offer more opportunity to test for the presence of pottery bearing sites.

Returning to the issue of "Polynesian outliers" noted above, our initial investigations appear largely to conform to the Shutler and Shutler (1967:98) observation that there is little to differentiate the material culture of Futuna and Aniwa from that of neighboring Aneityum and Tanna. This combined with linguistic evidence from Tanna showing some Polynesian influence (Lynch 1996) suggests that, if used critically, the notion of cultural hybridity might be usefully applied to this context (Silliman 2015).

In terms of human ecology and resource exploitation, the general pattern of shortterm and temporary habitation of coastal areas for fishing and shellfish gathering is common across southern Vanuatu, and indeed right across the Asia-Pacific region (Szabó and Amesbury 2011). Further analysis of recovered shell midden remains will allow us to possibly refine our observations in this regard. Additional work on agricultural and marine resource intensification will likewise allow us to tie these initial observations of cultural landscapes to our understanding both of changing 
human-environment relations and possibly the emergence of a Polynesian identity on Futuna and Aniwa.

Nonetheless, there remains a lot of work to be done. We therefore conclude with a few notes on the directions that SVAS is expected to develop in the near future. First, the SVAS project is going to allow us to bring a substantial amount of new data to bear on understanding regional dynamics in southern Vanuatu and more broadly in the western Pacific. The excavated materials retrieved by Shutler and Shutler will also be placed in a firmer context; further analyses using new technologies will provide some key information. The timing of processes such as the decision to abandon pottery use and production is critical for understanding everyday life in Oceanic societies in the past. New discoveries on Tanna suggest this may have been a more complex process than is sometimes imagined, as even near neighbors may have chosen to cease pottery production and use at different times and possibly for different reasons. There is the potential on Aniwa for discovering early (2000-3000 B.P.) archaeological deposits, though the initial survey indicates that the near-shore deposits are more recent, dating to within the last 1000 years at most. This and other evidence suggests the island has been uplifting for some time, so these deposits may be present on higher terraces rather than the present shoreline.

Second, what we know about the long-term regional dynamics of southern Vanuatu is likely to be essential to broader discussions on political economy in Oceanic societies (Kirch 2010a; Earle and Spriggs 2015). Our initial impression, especially on Futuna, is that the widespread stone terracing reflects recent processes of agricultural intensification, similar to that witnessed in neighboring Aneityum (Spriggs 1981, 1986) and Polynesian East Futuna (Kirch 1994). However, unlike models that tend to link intensification to resource control and centralization of hierarchies, we suspect that Futuna and Tanna, with their more heterarchical chiefly systems, offer alternative pathways through sociopolitical complexity. We plan to explore these processes both in landscape surveys (particularly on Futuna) and by examining village-level dynamics through intensive excavations of sites with intact features that can tell us about the domestic economy and everyday life on these islands in the past. As noted above, we have already discovered subsurface intact combustion features in open sites along the beaches relating to the most recent 1000 years of human history on Futuna and Aniwa. These kinds of sites are important for understanding daily life at the village level in island societies through time.

Third, the scope for learning about interisland exchanges is immense. This includes the shorter-distance exchanges between the intervisible islands in TAFEA Province and longer-distance voyaging and exchange. Did Aniwa's proximity to Tanna result in the island serving as a satellite of sorts to the larger island, while more remote Futuna was more independent? Are Futuna's stone terraces a reflection of stronger ties to Aneityum? We already know that there are strong links between southern Vanuatu and the Loyalty Islands to the west (Dubois 1996). Research in northern Vanuatu suggested important links to Fiji to the east (Bedford and Spriggs 2008). The linguistics and folklore of Futuna and Aniwa, and to a lesser degree Tanna, clearly indicate Polynesian connections.

We need to add more of the archaeological perspective to the story. That will better allow us to refine our understanding of the timing and nature of settlement processes from Polynesia into areas of already densely settled islands. Was the secondary Polynesian settlement of southern Vanuatu a long or short process? Was the situation a 
large-scale migration or did a few canoes land and establish chiefly settlements that eventually resulted in linguistic changes? The latter situation appears to have been the scenario on Efate, where Samoans are recorded as having arrived and settled before European contact (Turner 1861). To tease out answers to these questions, we foresee analyzing a range of sources of information, including evidence for stone tool exchanges and potentially adze form. On coral Aniwa, all volcanic stone is imported, and we know that oven stones were and are brought there from Erromango and Tanna. Adzes presumably came from neighboring islands, but we would also expect evidence of more exotic specimens to emerge through geochemical analyses. Other artifact forms such as shell ornaments or fishhooks are also likely to confirm Polynesian influence. Other lines of evidence would be the archaeologies of village life, mortuary practices, and bioarchaeological study of human remains including isotopes and aDNA analysis. Did domestic space change with the arrival of Polynesians? What about burial practices and the treatment of the dead? While we cannot answer all these questions now, they reflect some of the directions in which our research will develop in future.

\section{ACKNOWLEDGMENTS}

We thank our friends and collaborators on the islands of Futuna, Aniwa, and Tanna who made this work possible. The two Vanuatu Cultural Centre fieldworkers for Aniwa, Denise Elena and David Samaria, were always encouraging and supportive. Two anonymous reviewers and the editors of Asian Perspectives provided useful comments and guidance that improved this article. This research is supported by an Australian Research Council Discovery Grant (DP160103578) and Valentin's travel to Vanuatu by CNRS UMR 7041.

\section{REFERENCES CITED}

ADAMS, RON

1984 In the Land of Strangers: A Century of European Contact with Tanna, 1774-1874. Canberra: Australian National University.

Addison, David J., and Elizabeth Matisoo-Smith

2010 Rethinking Polynesian origins: A West Polynesia Triple-I model. Archaeology. Oceania 45(1):1-12.

Beaglehole, James C., ed.

1969 The Journals of Captain James Cook on His Voyages of Discovery: The Voyage of the Resolution and Adventure 1772-1775. Cambridge: Hakluyt Society.

BedFord, STUART

2006 Pieces of the Vanuatu Puzzle: Archaeology of the North, South and Centre. Terra Australis 23. Canberra: Pandanus Press, RSPAS, ANU Press. Ebook available at: https://press.anu.edu.au/ node/349/download.

Bedford, Stuart, and Matthew Spriggs

2008 Northern Vanuatu as a Pacific crossroads: The archaeology of discovery, interaction, and the emergence of the "ethnographic present". Asian Perspectives 47(1):95-120.

2014 The archaeology of Vanuatu: 3000 years of history across islands of ash and coral, in The Oxford Handbook of Prehistoric Oceania, ed. E. Cochrane and T. Hunt. Oxford: Oxford University Press. Published on Oxford Handbooks Online (website) at: www.oxfordhandbooks.com/view/ 10.1093/oxfordhb/9780199925070.001.0001/oxfordhb-9780199925070-e-015

Bedford, Stuart, Matthew Spriggs, and Richard Shing

2016 "By all means let us complete the exercise": The 50-year search for Lapita on Aneityum, southern Vanuatu and implications for other "gaps" in the Lapita distribution. Archaeology in Oceania 51(2):122-130. 
BONNEMAISON, JOËL

1994 The Tree and the Canoe: History and Ethnogeography of Tanna. Honolulu: University of Hawai' $\mathrm{i}$ Press.

Bronk Ramsey, Christopher

2013 OxCal Program v4.2.4. Radiocarbon Accelerator Unit. University of Oxford.

BRUnTON, RON

1979 Kava and the daily dissolution of society on Tanna, New Hebrides. Mankind 12(2):93-103.

1989 The Abandoned Narcotic: Kava and Cultural Instability in Melanesia. Cambridge: Cambridge University Press.

Burley, David V.

2013 Fijian Polygenesis and the Melanesian/Polynesian divide. Current Anthropology 54(4):436-463.

Capell, Arthur

1958 The Culture and Language of Futuna and Aniwa, New Hebrides. Sydney: University of Sydney.

Carney, J. N., and A. MacFarlane

1971 Geology of Tanna, Aneityum, Futuna, and Aniwa. Port Vila: New Hebrides Geological Survey.

Carson, Michael T.

2012 Recent developments in prehistory. Perspectives on settlement chronology, inter-community relations, and identity formation, in Polynesian Outliers: The State of the Art: 27-48, ed. R. Feinberg and R. Scaglion. Pittsburgh: University of Pittsburgh Press.

Clark, Geofrrey

2014 Social memory and the langi (royal tombs) of Lapaha, Tonga, in Monuments and People in the Pacific: 221-244, ed. H. Martinsson-Wallin and T. Thomas. Studies in Global Archaeology 20. Uppsala: Uppsala University.

Colley, H., and R. P. Ash

1971 The Geology of Erromango. New Hebrides: The British Service.

Crowley, Terry

2000 The language situation in Vanuatu. Current Issues in Language Planning 1:47-132.

Dubois, Marie-Joseph

1996 Vanuatu seen from Maré, in Arts of Vanuatu: 79-82, ed. J. Bonnemaison, C. Kaufmann, K. Huffman, and D. Tryon. Honolulu: University of Hawai'i Press.

Earle, Tim K., and Matthew Spriggs

2015 Political economy in prehistory: A Marxist approach to Pacific sequences. Current Anthropology 56(4):515-544.

Feinberg, R., and R. Scaglion, eds.

2012 Polynesian Outliers: The State of the Art. Pittsburgh: University of Pittsburgh Press.

FLeXner, James L.

2014 Mapping local perspectives in the historical archaeology of Vanuatu mission landscapes. Asian Perspectives 53(1):2-28.

2016 An Archaeology of Early Christianity in Vanuatu: Kastom and Religious Change on Tanna and Erromango, 1839-1920. Canberra: The Australian National University Press.

Flexner, James L., and Edson Willie

2015 Under the mission steps: An 800 year-old human burial from south Tanna, Vanuatu. Journal of Pacific Archaeology 6(1):49-55.

Flexner, James L., Edson Willie, Andrew Z. Lorey, Helen Alderson, Robert Williams, and Samson IERU

2016 Iarisi’s domain: Historical archaeology of a Melanesian village, Tanna Island, Vanuatu. Journal of Island and Coastal Archaeology 11(1):26-49.

François, Alexandre

2012 The dynamics of linguistic diversity: Egalitarian multilingualism and power imbalance among northern Vanuatu languages. International Journal of the Sociology of Language 214:85-110.

GARANGER, JosÉ

1972 Archéologie des Nouvelles-Hébrides [Archaeology of the New Hebrides]. Paris: Musée de l'Homme. 
Gray, WiLLiAM

1894 Four Aniwan songs. Journal of the Polynesian Society 3(2):93-97.

Groube, Les

1975 ArchaeologicalResearch in Aneityum. South Pacific Bulletin 25:27-30.

Guiart, JEAN

1956 Un Siècle et Demi de Contacts Culturels à Tanna, Nouvelles-Hébrides [A century and a half of cultural contacts with Tanna, New Hebrides]. Paris: Musée de l'Homme.

Hofman, Corinne L., Alistair J. Bright, Arie Boomert, and Sebastiaan Knippenberg

2007 Island rhythms: The web of social relationships and interaction networks in the Lesser Antillean Archipelago between 400 B.C. and A.D. 1492. Latin American Antiquity 18(3):243-268.

Humphreys, Clarence B.

1926 The Southern New Hebrides: An Ethnological Record. Cambridge: Cambridge University Press.

Keller, Janet D., and Takaronga Kuautonga

2007 Nokonofo Kitea, We Keep on Living this Way: Myths and Music of Futuna, Vanuatu. Adelaide: Crawford House Publishing.

Kirch, Patrick V.

1994 The Wet and the Dry: Irrigation and Agricultural Intensification in Polynesia. Chicago: University of Chicago Press.

2010a How Chiefs Became Kings: Divine Kingship and the Rise of Archaic States in Ancient Hawaii. Berkeley: University of California Press.

2010 b Peopling of the Pacific: A Holistic Anthropological Perspective. Annual Review of Anthropology 39:131-148.

Kirch, Patrick V., and Roger C. Green

1987 History, phylogeny, and evolution in Polynesia. Current Anthropology 28(4):431-456.

2001 Hawaiki, Ancestral Polynesia: An Essay in Historical Anthropology. Cambridge: Cambridge University Press.

Kirch, Patrick V., and Jean-Louis Rallu

2007 The Growth and Collapse of Pacific Island Societies: Archaeological and Demographic Perspectives. Honolulu: University of Hawai'i Press.

Kirch, Patrick V., ANd Jillian SwifT

2017 New AMS radiocarbon dates and re-evaluation of cultural sequence of Tikopia, Southeast Solomon Islands. Journal of the Polynesian Society 126(3):313-336.

Kirch, Patrick V., and Douglas E. Yen

1982 Tikopia: The Prehistory and Ecology of a Polynesian Outlier. Honolulu: B. P. Bishop Museum.

Leach, Foss, and Janet Davidson

2008 The Archaeology of Taumako: A Polynesian Outlier in the Eastern Solomon Islands. Auckland: New Zealand Journal of Archaeology Special Publication.

LiNDSTROM, LAMONT

1990 Knowledge and Power in a South Pacific Society. Smithsonian Series in Ethnographic Inquiry. Washington, DC: Smithsonian Institute Press.

1996 Arts of language and space, south-east Tanna, in Arts of Vanuatu: 123-128, ed. J. Bonnemaison, C. Kaufmann, K. Huffman, and D. Tryon. Honolulu: University of Hawai'i Press.

LiUA'ANA, FeATUNA'I

1996 Errand of Mercy: Samoan Missionaries to Southern Vanuatu, 1839-60, in The Covenant Makers: Islander Missionaries in the Pacific: 41-79, ed. D. Munro and A. Thornley. Suva, Fiji: Pacific Theological Seminary and Institute of Pacific Studies at University of the South Pacific.

LYNCH, JOHN

1996 Kava-drinking in southern Vanuatu: Melanesian drinkers, Polynesian roots. Journal of the Polynesian Society 105(1):27-40.

2001 The Linguistic History of Southern Vanuatu. Canberra: Research School of Pacific and Asian Studies, Australian National University.

Martinsson-Wallin, Helene

2014 Archaeological investigations in Independent Samoa: "Tala Eli" of Laupule Mound and beyond, in Monuments and People in the Pacific: 245-272, ed. H. Martinsson-Wallin and T. Thomas. Studies in Global Archaeology 20. Uppsala: Uppsala University. 
McArthur, Norma

1981 New Hebrides Population 1840-1967: A Re-interpretation. Noumea: South Pacific Commission.

McArthur, Norma, and John Yaxley

1968 Condominium of the New Hebrides: A Report on the First Census of the Population, 1967. Sydney: V.C.N. Blight, Government Printer.

NeEf, G., AND M. T. McCullough

2001 Pliocene-Quaternary history of Futuna Island, south Vanuatu, southwest Pacific. Australian Journal of Earth Sciences 48:805-814.

Nehrbass, KenNETH

2012 A Comprehensive Comparison of Lexemes in the Major Languages of Tanna, Vanuatu. Dallas: SIL International. SIL eBook 34, available at: www-01.sil.org/silepubs/Pubs/928474547767/eBook_34_Nehrbass_Tanna_Vanuatu.pdf

Paton, John G.

1907 John G. Paton, Missionary to the New Hebrides. New York: Fleming H. Revell Company.

Petchey, Fiona, Atholl Anderson, Alan Hogg, and Albert Zondervan

2008 The marine reservoir effect in the Southern Ocean: An evaluation of extant and new DR values and their application to archaeological chronologies. Journal of the Royal Society of New Zealand 38(4):243-262.

Petchey, Fiona, Matthew Spriggs, Foss Leach, Mike Seed, Christophe Sand, Michael Pietrusewsky, AND Kay ANDERSON

2011 Testing the human factor: Radiocarbon dating the first peoples of the South Pacific. Journal of Archaeological Science 38(1):29-44.

Reimer, Paula J., Edouard Bard, Alex Bayliss, J. Warren Beck, Paul G. Blackwell, Christopher Bronk Ramsey, Caitlin E. Buck, Hai Cheng, R. Lawrence Edwards, Michael Friedrich, Pieter M. Grootes, Thomas P. Guilderson, Hafidi Haflidason, Iika Hajdas, Christine Hatté, Timothy J. Heaton, Dirk L. Hoffman, Allen G. Hogg, Konrad A. Hughen, K. Felix Kaiser, Bernd Kromer, Sturt W. Manning, Mu Niu, Ron W. Reimer, David A. Richards, E. Marian Scott, John R. Southon, Richard A. Staff, Christian S. M. Turney, and Johannes Van Der Plicht

2013 IntCal13 and Marine13 radiocarbon age calibration curves 0-50,000 years cal B.P. Radiocarbon 55(4):1869-1887.

Sand, Christophe, and Stuart Bedford, eds.

2010 Lapita: Ancêtres Océaniens, Oceanic Ancestors. Paris: Musée du Quai Branly, Somogy éditions d'art.

Sand, Christophe, Scarlett Chiu, and Nicholas Hogg, eds.

2015 The Lapita Cultural Complex in Time and Space: Expansion Routes, Chronologies and Typologies. Archeologica Pasifika 4. Nouméa: Institut d'archéologie de la Nouvelle-Calédonie et du Pacifique.

SCARR, DERYCK

1967 Recruits and recruiters: A portrait of the Pacific islands labour trade. Journal of Pacific History 2:5-24.

SHINEBERG, Dorothy

1967 They Came for Sandalwood: A Study of the Sandalwood Trade in the South West Pacific, 1830-1865. Melbourne: Melbourne University Press.

Shutler, Mary E., and Richard Shutler

1966 A preliminary report of archaeological explorations in the southern New Hebrides. Asian Perspectives 9:157-166.

1967 Origins of the Melanesians. Archaeology and Physical Anthropology in Oceania 2:91-99.

Shutler, Mary E., Richard Shutler, and Stuart Bedford

2002 Further detail on the archaeological explorations in the Southern New Hebrides, 1963-1964, in Fifty Years in the Field: Essays in Honour and Celebration of Richard Shutler Jr's Archaeological Career: 189-205, ed. S. Bedford, C. Sand, and D. V. Burley. Auckland: New Zealand Archaeological Association.

SHUTLER, RiCHARD

1973 New Hebrides radiocarbon dates, 1968. Asian Perspectives 14:84-87. 
Silliman, Stephen W.

2015 A requiem for hybridity? The problem with Frankensteins, purées, and mules. Journal of Social Archaeology 15(3):277-298.

Specht, James, Chris Gosden, Christina Pavlides, Zoe Richards, and Glenn Summerhayes

2016 Exploring Lapita diversity on New Britain's south coast, Papua New Guinea. Journal of Pacific Archaeology 7(1):20-29.

SPriggs, Matthew

1981 Vegetable kingdoms: Taro irrigation and Pacific prehistory. Ph.D. dissertation. Australian National University, Canberra.

1984 The Lapita cultural complex: Origins, distribution, contemporaries and successors. Journal of Pacific History 19(4):202-223.

1986 Landscape, land use, and political transformation in southern Melanesia, in Island Societies: Archaeological Approaches to Evolution and Transformation: 6-19, ed. P. V. Kirch. Cambridge: University of Cambridge Press.

1999 Pacific archaeologies: Contested ground in the construction of Pacific history. Journal of Pacific History 34(1):109-121.

2007 Population in a vegetable kingdom: Aneityum Island (Vanuatu) at European contact in 1830, in The Growth and Collapse of Pacific Island Societies: Archaeological and Demographic Perspectives: 278-305, ed. P. V. Kirch and J.-L. Rallu. Honolulu: University of Hawai`i Press.

STEWARD, JULIAN H.

1942 The direct historical approach to archaeology. American Antiquity 7(4):337-343.

Szabó, Katherine, And Judith R. Amesbury

2011 Molluscs in a world of islands: The use of shellfish as a food resource in the tropical island AsiaPacific region. Quarternary International 239:8-18.

Terrell, John EDWARD

2011 Recalibrating Polynesian prehistory. Proceedings of the National Academy of Sciences 108(5):1753-1754.

Turner, George

1861 Nineteen Years in Polynesia: Missionary Life, Travels, and Researches in the Islands of the Pacific. London: John Snow.

Valentin, Frederique, Matthew Spriggs, Stuart Bedford, and Hallie Buckley

2011 Vanuatu mortuary practices over three millennia: Lapita to the early European Contact period. Journal of Pacific Archaeology 2(2):49-65.

VAn Trease, Howard

1987 The Politics of Land in Vanuatu. Suva: University of the South Pacific Press.

WiLSON, MEREDith

1999 Bringing the art inside: A preliminary analysis of black linear rock-art from limestone caves in Erromango, Vanuatu. Oceania 70(1):87-97.

2002 Picturing Pacific prehistory: The rock-art of Vanuatu in a western Pacific context. Ph.D. Thesis. Australian National University, Canberra. 